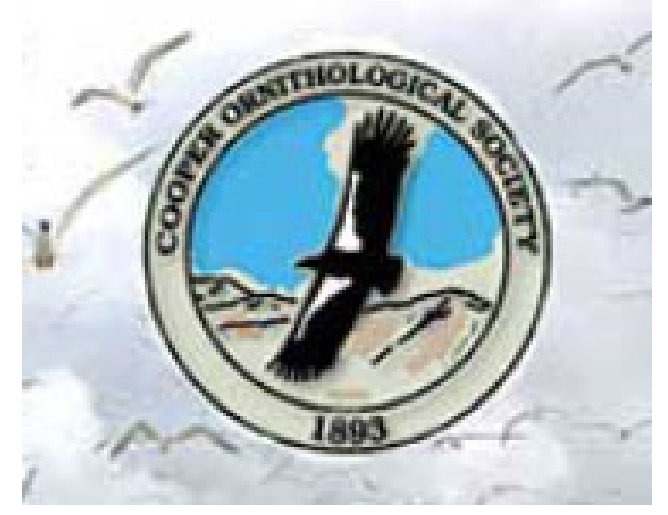

The Timing of Pair Formation in Harlequin Ducks

Author(s): Gregory J. Robertson, Fred Cooke, R. Ian Goudie, W. Sean Boyd

Reviewed work(s):

Source: The Condor, Vol. 100, No. 3 (Aug., 1998), pp. 551-555

Published by: University of California Press on behalf of the Cooper Ornithological Society

Stable URL: http://www.jstor.org/stable/1369723

Accessed: 23/04/2012 23:02

Your use of the JSTOR archive indicates your acceptance of the Terms \& Conditions of Use, available at http://www.jstor.org/page/info/about/policies/terms.jsp

JSTOR is a not-for-profit service that helps scholars, researchers, and students discover, use, and build upon a wide range of content in a trusted digital archive. We use information technology and tools to increase productivity and facilitate new forms of scholarship. For more information about JSTOR, please contact support@jstor.org. 


\title{
THE TIMING OF PAIR FORMATION IN HARLEQUIN DUCKS ${ }^{1}$
}

\author{
GREGORY J. ROBERTSON² AND FRED COOKE \\ Department of Biological Sciences, Simon Fraser University, Burnaby, British Columbia, V5A 1S6, Canada \\ R. IAN GoudiE ${ }^{3}$ AND W. SEAN BOYD \\ Pacific Wildlife Research Centre, Canadian Wildlife Service, 5421 Robertson Road, RR\#1, Delta, \\ British Columbia, V4K 3N2, Canada
}

\begin{abstract}
The timing of pair formation varies within and among species of ducks. In this study we documented the chronology of pair formation in a population of wintering Harlequin Ducks (Histrionicus histrionicus) in southwestern British Columbia. Harlequin Ducks began forming pair bonds in October and over half of the females were paired by December. This timing is much earlier than other ducks of similar size. A segment of this population was individually marked, and we documented the reunion of mates in subsequent years. In all cases where both members of the pair returned to their wintering grounds they reunited in the fall. New pair bonds, involving young males and females, were formed in the spring. We suggest that pair reunion in this species reduces the costs of courtship and pair bond maintenance and allows males to pair early in the nonbreeding season, compared to other species.
\end{abstract}

Key words: Harlequin Duck, Histrionicus histrionicus, pair formation, pair reunion.

In many migratory bird species pair bonds are formed just before the breeding season (Oring 1982). Females arrive at the breeding grounds and select males based upon their individual quality or on the quality of the territory they hold (Hixon 1987). Waterfowl do not follow this pattern. In geese and swans the pair bond is maintained throughout the entire year and across years. In ducks, pair bonds usually are formed during the preceding fall, winter, or spring, depending upon the species (Rohwer and Anderson 1988). Intense selection for mates has led to the evolution of early pairing, sometimes up to seven months before breeding. Males benefit by obtaining a mate, females benefit by being protected by a mate which allows her to optimize her foraging rates during the prebreeding season (Ashcroft 1976, Scott 1980).

The timing of pairing varies considerably within and

\footnotetext{
${ }^{1}$ Received 27 October 1997. Accepted 5 January 1998.

${ }^{2}$ Present address: Canadian Wildlife Service, 6 Bruce Street, Mount Pearl NF A1N 4T3, Canada, e-mail: greg.robertson@ec.gc.ca

${ }^{3}$ Present address: Harlequin Duck Conservation Society, Eastern Office, 17 Waterford Bridge Road, St. John's, Newfoundland, A1E 1C5, Canada.
}

among species (Rohwer and Anderson 1988). Explanations for these differences among species include the timing of breeding, food quality, and sex ratio of the species (McKinney 1992). Among species, early pairing tends to be correlated with body size (Rohwer and Anderson 1988). Larger species have several energetic advantages that allow them extra time for other activities (Goudie and Ankney 1986), including pairing. Although larger species require absolutely more food, they have lower metabolic rates and are more efficient with the same amount of food (Calder 1974). Additionally, larger species have thermodynamic advantages that slows the rate of body heat loss and lowers their thermoneutral temperature zone (Calder 1974). Therefore, larger species are able to court and to maintain pair bonds throughout inclement weather conditions in winter. Smaller males may not be able to devote the extra energy to courtship and mate guarding until favorable weather during spring (Rohwer and Anderson 1988). This led Rohwer and Anderson (1988) to formulate the male costs-female benefits hypothesis for the timing of pair formation. Pairing is predicted to occur when the female benefits from being paired, which is assumed to be early in the nonbreeding season because paired females enjoy a higher dominance status and access to preferred food resources (Ashcroft 1976, Paulus 1983). Males may also be selected to form pair bonds early, if they can form a pair bond with high quality females or elevate their own social status by doing so (Wishart 1983, Heitmeyer 1995). The timing of pair formation is modified by the energetic costs to males of maintaining the pair bond. Therefore, the timing of pair formation depends on the relative costs and benefits to males and females in maintaining the pair bond. Within species, older males and males in prime condition tend to successfully obtain a mate sooner than young males and males in poor condition (Brodsky and Weatherhead 1985, Hepp 1986).

The pairing chronology of sea ducks (Mergini) is not well known. They represent a monophyletic clade that exhibits wide variation in life history characters and body size (Livezey 1995). Pairing begins as early as September in Common Eiders (Somateria mollissima) (Spurr and Milne 1976) and as late as March (possibly even during spring migration) in mergansers and Buffleheads (Bucephala albeola) (Erskine 1972, Hohman et al. 1992). In some species of sea ducks, after a period of separation during brood rearing, individuals 
are known to reunite with the same mate, in some cases for a number of consecutive years (Bengtson 1972, Spurr and Milne 1976, Savard 1985).

Harlequin Ducks (Histrionicus histrionicus) represent an interesting case as they are a relatively small sea duck that begins to form pair bonds in October (Gowans et al. 1997). Harlequin Ducks also are known to reunite with the same mate in subsequent years (Bengtson 1972, Gowans et al. 1997). In this study we identify factors that influence the timing of pair formation among individual Harlequin Ducks. Specifically, the objectives of this study were to (1) document the pairing chronology of Harlequin Ducks over the entire nonbreeding season and (2) determine whether variation in the timing of pair formation is related to an individual's age and/or the presence of a prior mate at the nonbreeding grounds.

\section{METHODS}

\section{STUDY AREA}

This study was conducted from August 1994 to May 1997 on a $5.5 \mathrm{~km}$ stretch of rocky shoreline near the town of White Rock, in coastal southwestern British Columbia. The study area is bounded by mud flats on either side which are not used by Harlequin Ducks. Up to 150 Harlequin Ducks molt and winter at this site (Robertson et al. 1997). Access to the site is provided by a railway line on a dike that runs 2 to $4 \mathrm{~m}$ above the intertidal zone along the entire shoreline.

\section{FIELD METHODS}

Harlequin Ducks were captured annually during the wing molt in July (males) and September (females) from 1994 to 1996. Researchers in sea kayaks corralled flightless individuals into a drive trap placed on an intertidal bench. All individuals captured were sexed and aged by cloacal examination using the depth of the Bursa of Fabricius (Peterson and Ellarson 1978) and plumage characters to identify juveniles. Age was classified as either juvenile (hatched in the same summer as the banding), yearling (bursa depth $<10 \mathrm{~mm}$ ), subadult (bursa depth $>10 \mathrm{~mm}$ ), and adults (no bursa) (Goudie, unpubl. data). Each individual was marked with a unique colored tarsal leg band engraved with a two-digit alphanumeric code and a standard U.S. Fish and Wildlife Service aluminum band. Birds were released in small groups after processing.

Surveys of birds on the study site were conducted regularly (about once per week) throughout the year. During each survey, observers noted the location and group composition of all Harlequin Ducks. Unlike most other sea ducks, Harlequin Ducks prefer to remain within about $50 \mathrm{~m}$ of the shoreline, and accurate population counts are feasible. Harlequin Ducks rest and preen on rocks, and at this time the tarsal band can be read. Pairs were identified by the methods described in Gowans et al. (1997). Briefly, individuals were considered paired if they behaved synchronously, remained close together, and the male was seen to guard the female from other males. A particular effort was made to identify pairs in which one, or both, of the members of the pair carried tarsal bands. The first time a pair was observed represents a biased estimate of when the pair bond formed; birds could have been paired for months before they were identified, so our estimate of the timing of pair formation represents the latest possible time a pair bond could have formed. The pairing status (including birds definitely not paired) of an individual was considered confirmed if they were observed as noted above at least three different times.

The nonbreeding season was broadly classified into molt (June through September), fall (October to midDecember), winter (mid-December to February), and spring (March to mid-May).

\section{RESULTS}

\section{TIMING OF PAIRING}

The chronology of pair formation was very similar over the three seasons (Fig. 1). The first pairs were seen in early October, and by mid-December approximately 60 to $80 \%$ of females were paired. Through March and April the proportion of females paired approached $100 \%$ in all three years.

\section{PAIR REUNION}

In 1994, six pairs were identified where both the male and female were banded. Four (67\%) of these pairs reunited in 1995, and in all four cases the birds were observed paired for the first time in the fall. In the other two cases the male returned and the female was never seen. One of these males remained in the study area for the 1995-1996 nonbreeding season and was observed courting other females but was never successful in obtaining a mate. He also returned to the study area to molt in the summer and fall of 1996, but left the study area after the molt. The other male was seen intermittently over the next two nonbreeding seasons. He was observed once, possibly paired, in the spring of 1996 and once, apparently unpaired, in the spring of 1997. Only one possible case of pair divorce occurred, where a male was seen with an unmarked female in 1994-1995 and was seen with a banded female (from the 1994-1995 marked cohort) in the following year.

In 1995,11 pairs were identified where both the male and female were banded (including the 4 pairs that were identified in 1994-1995). Eight of these pairs reunited in 1996-1997. All but two (75\%) of these pairs were seen for the first time in the fall. Of the remaining three pairs, the males returned and the females did not. One of these males left the study area after the molt, another male remained in the study area and was seen unpaired in the spring of 1997, and the last male was observed paired with a different female (a subadult) in the spring.

\section{AGE AND TIMING OF PAIRING}

In general, females paired at a younger age and with a higher frequency than males (Table 1). All females were paired by the time they were subadults, whereas $33 \%$ of adult males remained unpaired.

\section{DISCUSSION}

Harlequin Ducks began to form pair bonds in the fall, with well over half of the females paired by December, and all females paired by April. If both members of a pair returned to the wintering grounds, they reunited 

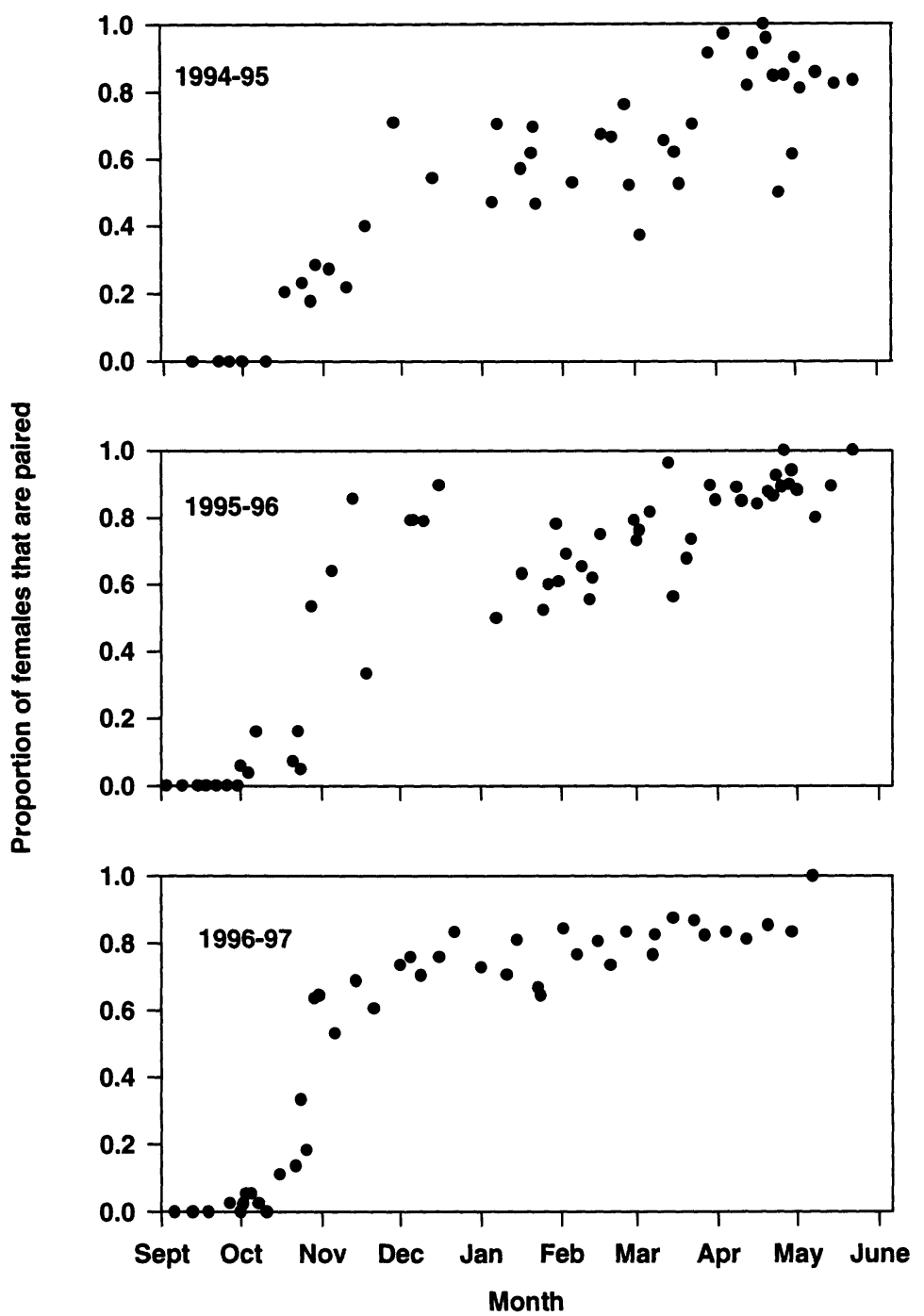

FIGURE 1. Pairing chronology of female Harlequin Ducks at White Rock, British Columbia. Sample sizes range from 5 to 67 females, low samples sizes $(<10)$ occur at end of the nonbreeding season (May) when most females have left for the breeding grounds.

in the fall. Young females (yearlings and subadults) pairing for the first time did so in the spring. One yearling male was able to establish a pair bond, yet a third of the male Harlequin Duck population remained unpaired.

Paired Harlequin Ducks are seen much earlier than pairs of other waterfowl species of a similar size. Among dabbling ducks, pair bonds are first seen in fall in larger species and in spring in smaller species (Rohwer and Anderson 1988). Males of smaller dabbling duck species may be unable to expend extra energy maintaining a pair bond and maintain a balanced energy budget during the cold weather and short days of the mid-winter months. Therefore, they must wait until spring before courting females. All of the pochards form pair bonds in spring, even the large bodied Canvasback (Aythya valisineria) (Weller 1965). Pochards, in contrast to dabblers, dive for food. In divers, males may not be able to efficiently defend a female from harassment or economically defend a food resource, so there are no benefits to pairing before spring for either sex. Smew (Mergus albellus) (Nilsson 1974), Oldsquaw (Clangula hyemalis) (Alison 1975), and Bufflehead (Erskine 1972) are sea ducks similar or smaller in size to Harlequin Ducks, and all of these species are first seen paired in the spring. Given that Harlequin Ducks are both small and dive for food, they would be expected to pair in the spring, yet this is not the case. Two related factors may explain why Harlequin Ducks pair earlier than other species of similar size. 
TABLE 1. Timing of pairing in different age and sex classes of Harlequin Ducks at White Rock, BC.

\begin{tabular}{lccc}
\hline \hline Sex and age & $\begin{array}{c}\text { Paired in falla }^{\mathrm{a}} \\
\text { (1 October- } \\
\text { 15 December) }\end{array}$ & $\begin{array}{c}\text { Paired in spring } \\
\text { (1 March- } \\
\text { 15 May) }\end{array}$ & Never paired \\
\hline Females & & & \\
juveniles & $1(0 \%)$ & $0(0 \%)$ & $1(100 \%)$ \\
yearlings & $0(0 \%)$ & $4(80 \%)$ & $1(20 \%)$ \\
subadults & $1(20 \%)$ & $4(80 \%)$ & $0(0 \%)$ \\
adults & $16(52 \%)$ & $15(48 \%)$ & $0(0 \%)$ \\
Males & & & \\
yearlings & $0(0 \%)$ & $1(50 \%)$ & $1(50 \%)$ \\
subadults & $0(0 \%)$ & $0(0 \%)$ & $2(100 \%)$ \\
adults & $11(27 \%)$ & $16(40 \%)$ & $13(33 \%)$ \\
\hline
\end{tabular}

a Some individuals that paired in the fall were not seen as paired until the spring. Therefore, the number of individuals that paired in fall is underestimated and the number that paired in spring is overestimated.

One is that they prefer to forage in relatively shallow waters along the intertidal zone, a relatively inexpensive foraging method for a diving duck (Goudie and Ankney 1988). The other is that established pairs reunite every fall.

Male sea ducks abandon their mates while they are incubating and depart to a molting location which may be a substantial distance from the breeding locations (Salomonsen 1968). Females may join in these migrations at a later date or molt on the breeding grounds. Males and females are separated for at least some period of time. Therefore, individuals must be site faithful to the location where they first formed their pair bond in order for pair reunion to occur. Since pairs are formed sometime between fall and spring in Harlequin Ducks, they should exhibit fidelity to their nonbreeding grounds. Site fidelity also is expected to be favored in species that use stable habitats. Harlequin Ducks use a relatively predictable habitat in the winter and are faithful to their wintering grounds (Robertson, unpubl. data), allowing pairs to reunite every fall. A potential benefit for early pair reunion is the ability for an individual to determine if their mate has survived the breeding and molting season. Individuals that lose their mate can begin courting another mate as soon as possible.

Pairs that reunite do so in the fall, whereas new pair bonds (including young females) are apparently established in spring. If only new pairs are considered and not pairs that reunite, Harlequin Ducks do follow the predicted pattern for a small diving species; that is they pair in spring. During the winter months, it may not be possible for males to attract and effectively defend a new female while still maintaining a balanced energy budget, even if the males would gain the benefits of an increased social status from being paired. Males may have to forage at such a high rate that they cannot budget extra time for courtship activities. Indeed, foraging rates during December and January are high, over $70 \%$ of the days' activity is spent feeding (Goudie and Ankney 1986, Robertson, unpubl. data, Torres, unpubl. data). Other sea ducks show increased foraging rates during the mid-winter period as well (Nilsson 1970). Furthermore, even established pairs tend not to be close to each other during mid-winter, and in some cases it is not clear that the pair bond is intact (Boyd, pers. observ.; Torres, unpubl. data); thus males are investing little energy in mate guarding.

If the winter period is stressful for Harlequin Ducks why do pairs reunite in the fall? Savard (1985, adapted from Rowley 1983) discussed potential reasons for why pairs reunite, which included (1) obtaining a mate of known abilities, (2) maintaining the same territory, and (3) reducing the time and energy spent in courtship. Gowans et al. (1997) showed that courtship behavior increased dramatically in the fall, however they concluded that most of the behavior was mate guarding by repaired males and courtship by unpaired males. Mate guarding is probably not as energetically expensive as active courtship because courting males fly around to find females. Very little courtship was seen between pairs that reunite (Gowans et al. 1997). On the other hand, unpaired males courting females in the spring are very active (Robertson, pers. observ.). By saving time and energy in courtship, males and females are able to reunite in the fall and not have to wait until spring. Even if the costs are reduced for established pairs, they could still reunite in spring and not expend energy in any courtship activity and mate guarding. However, there may be costs to waiting until spring. Males in pair bonds gain social status and may have access to better quality foraging areas (Paulus 1983). Another important cost of waiting until the spring is that the other member of the pair may have found a new mate.

In systems where pairs reunite, the pool of available females is very small. If there is a sex ratio bias for males, as seen in virtually all duck populations (Bellrose et al. 1961, Sargeant and Raveling 1992) including Harlequin Ducks (Bengtson 1972), then the sex bias in the pool of unpaired birds is even higher. Only young females and females that have lost a mate are available for pairing. This situation has been taken to the extreme in the Chiloe Wigeon (Anas sibilatrix), a sedentary species that exhibits long-term pair bonds. Available females are sufficiently rare that unpaired adult males will court juvenile females so as to copulate with them when they are reproductively mature (Brewer 1991). This lack of available females may explain why male Harlequin Ducks reunite with the same mate as soon as possible and do not wait until spring. Females gain by obtaining a mate of known abilities (Savard 1985), and are protected from harassment while foraging (Ashcroft 1976). Therefore, early pairing seen in Harlequin Ducks may result from the increased sexual selection for available females. Other sea ducks that pair early reunite with the same mate. Common Eiders begin pairing in September (Spurr and Milne 1976) and Barrow's Goldeneye (Bucephala islandica) (Savard 1985) in November. However, there are documented cases of pairs reuniting in Oldsquaw (Alison 1975) and Bufflehead (Gauthier 1987), yet the first pairs are not seen until spring in these species. Therefore, pair reunion in a species is not a sufficient condition for early pair formation and other factors may constrain these species to wait until the spring to re-pair. Clearly, more information on the timing of pair formation and the frequency of pair reunion in other 
species are needed to determine which factors influence the timing of pairing in waterfowl.

We thank all of the people who helped catch, band, and survey Harlequin Ducks. R. Torres kindly provided us with unpublished information. I. J. Ball, E. F. Cassirer, M. E. Heitmeyer, and J.-P. L. Savard provided helpful comments on an earlier draft of this manuscript. This study received generous funding from the British Columbia Waterfowl Society, the Institute for Wetland and Waterfowl Research, the Canadian Wildlife Service (CWS), the Natural Sciences and Engineering Research Council of Canada (NSERC), the CWS/NSERC Wildlife Ecology Research Chair, and Simon Fraser University.

\section{LITERATURE CITED}

Alison, R. M. 1975. Breeding biology of the Oldsquaw (Clangula hyemalis). Ornithol. Monogr. 18.

AsHCROFT, R. E. 1976. A function of the pair bond in the Common Eider. Wildfowl 27:101-105.

Bellrose, F. C., T. G. ScotT, A. S. Hawkins, AND J. B. Low. 1961. Sex ratios and age ratios in Nortr American ducks. Ill. Nat. Hist. Surv. Bull. 27: 391-474.

Bengtson, S.-A. 1972. Breeding ecology of the Harlequin Duck (Histrionicus histrionicus) in Iceland. Ornis Scand. 3:1-19.

BREwer, G. 1991. Courtship of ducklings by adult male Chiloe Wigeon (Anas sibilatrix). Auk 108: 969-973.

Brodsky, L. M., AND P. J. WeATHERHEAd. 1985. Time and energy constraints on courtship in wintering American Black Duck. Condor 87:33-36.

CAldER, W. A., III. 1974. Consequences of body size for avian energetics, p. 86-151. In R. A. Paytner [ed.], Avian energetics. Nuttall Ornithol. Club 15, Cambridge, MA.

Erskine, A. J. 1972. Buffleheads. Can. Wildl. Monogr. Ser. No. 4.

GAUTHIER, G. 1987. Further evidence of long-term pair bonds in the ducks of the genus Bucephala. Auk 104:521-522.

Goudie, R. I., AND C. D ANKNEy. 1986. Body size, activity budgets and diets of sea ducks wintering in Newfoundland. Ecology 67:1465-1482.

$\rightarrow$ Goudie, R. I., AND C. D ANKNEY. 1988. Patterns of habitat use by sea ducks wintering in southeaster. Newfoundland. Ornis Scand. 19:249-256.

Gowans, B., G. J. RoBertson, AND F. CoOKE. 1997. Behaviour and chronology of pair formation by Harlequin Ducks Histrionicus histrionicus. Wildfowl 48:135-146.

HeitmeYeR, M. E. 1995. Influences of age, body condition, and structural size on mate selection bi dabbling ducks. Can. J. Zool. 73:2251-2258.

$\rightarrow$ HEPP, G. R. 1986. Effects of body weight and age on the time of pairing of American Black Ducks. Aul $\rightarrow$ 103:477-484

Hixon, M. A. 1987. Territory area as a determinant of mating systems. Am. Zool. 27:229-247.

Hohman, W. L., C. D. ANKNEY, AND D. H. Gordon. 1992. Ecology and management of postbreeding waterfowl, p. 128-189. In B. D. J. Batt, A. D. Afton, C. D. Ankney, D. H. Johnson, J. A. Kadlec, and G. L. Krapu [eds.], Ecology and management of breeding waterfowl. Univ. Minnesota Press, Minneapolis, MN.

Livezey, B. C. 1995. Phylogeny and evolutionary ecology of modern seaducks (Anatidae: Mergini). Condor 97:233-255.

MCKINNEY, F. 1992. Courtship, pair formation and signal systems, p. 214-250. In B. D. J. Batt, A. D. Afton, C. D. Ankney, D. H. Johnson, J. A. Kadlec, and G. L. Krapu [eds.], Ecology and management of breeding waterfowl. Univ. Minnesota Press, Minneapolis, MN.

NILSSON, L. 1970. Food-seeking activity of south Swedish diving ducks in the non-breeding season. Oikos 21:145-154.

NiLSSON, L. 1974. The behaviour of wintering Smew in southern Sweden. Wildfowl 25:84-88.

ORING, L. W. 1982. Avian mating systems, p. 1-92. In D. S. Farner, J. S. King, and K. C. Parkes [eds.], Avian biology, Vol. 6. Academic Press, New York.

Paulus, S. L. 1983. Dominance relations, resource use, and pairing chronology of Gadwalls in winter. Auk 100:947-952.

Peterson, S. R., AND R. S. Ellarson. 1978. Bursae, reproductive structures, and scapular color in wintering female Oldsquaws. Auk 95:115-121.

Robertson, G. J., F. COOKE, R. I. Goudie, AND W. S. BoYD. 1997. The timing of arrival and moult chronology of Harlequin Ducks Histrionicus histrionicus. Wildfowl 48:147-155.

RoHwEr, F. C., AND M. G. ANDERSON. 1988. Femalebiased philopatry, monogamy, and the timing of pair formation in migratory waterfowl. Current Ornithol. 5:187-221.

Rowley, I. 1983. Re-mating in birds, p. 331-360. In P. P. G. Bateson [ed.], Mate choice. Cambridge Univ. Press, Cambridge.

SAlOMONSEN, F. 1968. The molt migration. Wildfowl 19:5-24.

Sargeant, A. B., AND D. G. Raveling. 1992. Mortality during the breeding season, p. 396-422. In B. D. J. Batt, A. D. Afton, C. D. Ankney, D. H. Johnson, J. A. Kadlec, and G. L. Krapu [eds.], Ecology and management of breeding waterfowl. Univ. Minnesota Press, Minneapolis, MN.

SAVARD, J.-P. L. 1985. Evidence of long-term pair bonds in Barrow's Goldeneye (Bucephala islandica). Auk 102:389-391.

ScotT, D. K. 1980. Functional aspects of the pair bond in winter in Bewick's Swans (Cygnus columbianus bewickii). Behav. Ecol. Sociobiol. 7: 323-327.

SPURR, E., AND H. MiLnE. 1976. Adaptive significance of autumn pair formation in the Common Eider Somateria mollissima (L.). Ornis Scand. 7:85-89.

WELLER, M. W. 1965. Chronology of pair formation in some nearctic Aythya (Anatidae). Auk 82:227235.

Wishart, R. A. 1983. Pairing chronology and mate selection in the American Wigeon (Anas americana). Can. J. Zool. 61:1733-1743. 